\title{
PESYMIŚCI I OPTYMIŚCI. DWA PODEJŚCIA WOBEC PROBLEMU PROLIFERACJI BRONI JĄDROWEJ PO ZIMNEJ WOJNIE
}

Po zimnej wojnie proliferacja broni jądrowej jest nadal ważnym problemem stanowiącym wyzwanie dla bezpieczeństwa międzynarodowego. Pesymiści i optymiści, dwa podejścia wobec tego problemu, ukształtowane zostały w przeważającej mierze przez doświadczenia zimnowojennej rywalizacji pomiędzy USA a ZSRR. Po jej zakończeniu, debata przysłużyła się pogłębionej analizie skutków proliferacji, zwłaszcza w kontekście nuklearyzacji Indii i Pakistanu.

Celem artykułu jest przybliżenie obu tych stanowisk wobec następujących zagadnień:

1) wpływ czynnika nuklearnego na konflikty pomiędzy państwami;

2) skutki nuklearyzacji Indii i Pakistanu a bezpieczeństwo międzynarodowe;

3) skutki nuklearyzacji Iranu;

4) proliferacja broni jądrowej a terroryzm;

5) ograniczenia związane $z$ podejściem optymistycznym i pesymistycznym wobec proliferacji.

Bomba atomowa zmieniła podejście państw do wojny. Okazała się ona najbardziej niszczycielską bronią w dziejach ludzkości. W czasie zimnej wojny, zarówno USA jak i ZSRR intensywnie rozbudowywały swoje arsenały. Kolejnymi państwami, które znalazły się w posiadaniu broni jądrowej to: Wielka Brytania w 1952 roku, Francja w 1960 roku, ChRL w 1964 roku, Indie w 1974 roku, Izrael prawdopodobnie około 1970 roku, Pakistan w 1998 roku, Korea Północna w 2006 roku. Nie spełniły się prognozy z lat sześćdziesiątych XX wieku, że w przeciągu dwudziestu lat, liczba państw atomowych przekroczy liczbę 10. W okresie zimnowojennego wyścigu zbrojeń, USA jak i ZSRR przeznaczały olbrzymie nakłady finansowe na rozbudowę własnych arsenałów jądrowych ${ }^{1}$. Nuklearne odstraszanie stało się faktem wraz z zaawansowaniem programów atomowych i wprowadzeniem bomby wodorowej przy równoczesnym rozwoju technologii rakietowej ${ }^{2}$. Nie obyło się bez kryzysów. Najpoważniejszym z nich był kryzys karaibski. W tamtym czasie ZSRR posiadał 3322 głowice i bomby atomowe, gdy USA posiadały ich aż 27 297. Mimo tej wydawało się miażdżącej, bo prawie

1 B. Brodie, War and Politics, New York 1973, s. 412.

2 Jak zuważył Rupert Smith: „Istota odstraszania nuklearnego polega na tym, że siła której można użyć w odpowiedzi na atak, jest uważana za tak niszcząca, a jej następstwa są tak oczywiste, iż cenę, którą przyszłoby za to zapłacić, uważa się za zbyt wysoką [...]”. Cyt. za: R. Smith, Przydatność siły militarnej. Sztuka wojenna we współczesnym państwie, przekł. A. i J. Maziarscy, Warszawa 2010, s. 232 . 
dziesięciokrotnej przewagi, administracja J. F. Kennedy'ego nie miała żadnej gwarancji, że w pierwszym uderzeniu całkowicie wyeliminuje radziecki arsenał atomowy ${ }^{3}$. Nawet przy takiej dysproporcji nie ryzykowano konfliktu atomowego z obawy przed odwetem ze strony nawet kilku radzieckich ocalałych atomowych bomb i głowic. W 1967 roku, ówczesny sekretarz obrony USA Robert McNamara stwierdził na podstawie wywiadowczych danych, że radziecki arsenał broni jądrowej pod względem wielkości osiaggnął parytet z amerykańskim. R. McNamara pokreślił, że w razie konfliktu, obu supermocarstwom groziło gwarantowane zniszczenie (assured destruction). Donald Brennen dodał jeszcze słowo wzajemne (mutual) podkreślając, że dwie strony nie przetrwają wojny nuklearnej (MAD - Mutual Assured Destruction) ${ }^{4}$. Doktryna MAD wpisywała się w logikę nuklearnego odstraszania. Obok arsenałów, zarówno USA jak i ZSRR posiadały kilka systemów przenoszenia broni jądrowej przez: głowice umieszczone na rakietach międzykontynentalnych (ICBM - Intercontinental Ballistic Missile), strategiczne bombowce, wyrzutnie umieszczone na łodziach podwodnych (SSBM - Submarine Launched Ballistic Missile) czy głowic umieszczonych na rakietach średniego zasięgu (IRBM - Intermediate Range Ballistic Missile).

Pomimo tak rozbudowanego arsenału jądrowego, wraz ze środkami jego przenoszenia, okazało się, że zimnowojenne nuklearne odstraszanie nie było tak skuteczne wobec aktów agresji i konfliktów na peryferiach, angażujących pośrednio oba supermocarstwa poprzez wspieranie swoich regionalnych sojuszników. Konflikty w Indochinach, Afryce czy na Bliskim Wschodzie w epoce atomowej miały jednak dość ograniczony charakter i nie mogły doprowadzić do zasadniczej zmiany układu sił, z obawy przed zaangażowaniem się bezpośrednim któregoś z atomowych supermocarstw. Zatem czynnik ryzyka związany z użyciem broni jądrowej w istotny sposób wpływał na skalę regionalnych konfliktów, wyeliminował jedynie wojnę między supermocarstwami.

Wraz z bardzo szybko rozrastającymi się arsenałami jądrowymi pojawiło się pytanie, gdzie jest granica? Jak ujął ten problem w latach 80 -tych brytyjski polityk Denis Healer, z amerykańskiego olbrzymiego arsenału już 5\% wystarczało do skutecznego odstraszenia ZSRR, pozostałe $95 \%$ pozostawało do zapewnienia o tym amerykańską opinię publiczną . Przykładowo w USA w latach 1956-2009 wyprodukowanych zostało 66500 bomb i głowic jądrowych ${ }^{6}$. W 2002 roku pięć głównych mocarstw, należących do klubu atomowego (USA, Rosja, Chiny, Wielka Brytania i Francja) łącznie w swoich arsenałach posiadały 20000 głowic, w tej liczbie nie uwzględniono atomowych głowic do rakiet średniego zasięgu IRBM, których było dodatkowo około 10 tysięcy. Na podstawie wyliczeń autorów „Bulletin of the Atomic Scientists” w latach 1945-2002 wyprodukowanych na świecie zostało łącznie 128 tysięcy głowic ${ }^{7}$.

3 K. N. Waltz, Nuclear Myths and Political realities, „The American Political Science Review” 1990, Vol. 84, No. 3, s. 734.

${ }_{5}^{4}$ J. M. Siracusa, Nuclear Weapons. A Very Short Introduction, Oxford 2008, s. 68.

5 Ibidem, s. 73.

6 R. S. Norris, H. M. Kristensen, U.S. Nuclear Warheads, 1945-2009, „Bulletin of the Atomic Scientists", July/August 2009, s. 72.

7 Global nuclear stockpiles, 1945-2002, „Bulletin of the Atomic Scientists”, November 1, 2002, s. 103 . 
Tabela 1

Arsenały nuklearne w latach 1945-2002

\begin{tabular}{|c|c|c|c|c|c|c|}
\hline Lata & USA & ZSRR/Rosja & $\begin{array}{l}\text { Wielka } \\
\text { Brytania }\end{array}$ & Francja & ChRL & Lącznie \\
\hline 1 & 2 & 3 & 4 & 5 & 6 & 7 \\
\hline 1945 & 6 & & & & & 6 \\
\hline 1946 & 11 & & & & & 11 \\
\hline 1947 & 32 & & & & & 32 \\
\hline 1948 & 110 & & & & & 110 \\
\hline 1949 & 235 & 1 & & & & 236 \\
\hline 1950 & 369 & 5 & & & & 374 \\
\hline 1951 & 640 & 25 & & & & 665 \\
\hline 1952 & 1005 & 50 & 1 & & & 1056 \\
\hline 1953 & 1436 & 120 & 2 & & & 1559 \\
\hline 1954 & 2063 & 150 & 5 & & & 2218 \\
\hline 1955 & 3057 & 200 & 10 & & & 3267 \\
\hline 1956 & 4618 & 426 & 15 & & & 5059 \\
\hline 1957 & 6444 & 660 & 20 & & & 7124 \\
\hline 1958 & 9822 & 869 & 22 & & & 10713 \\
\hline 1959 & 15468 & 1060 & 25 & & & 15553 \\
\hline 1960 & 20434 & 1605 & 30 & & & 22069 \\
\hline 1961 & 24111 & 2471 & 50 & & & 26632 \\
\hline 1962 & 27297 & 3322 & 205 & & & 30824 \\
\hline 1963 & 29249 & 4238 & 280 & & & 33767 \\
\hline 1964 & 30751 & 5221 & 310 & 4 & 1 & 36287 \\
\hline 1965 & 31642 & 6129 & 310 & 32 & 5 & 38118 \\
\hline 1966 & 31700 & 7089 & 270 & 36 & 20 & 39115 \\
\hline 1967 & 30893 & 8339 & 270 & 36 & 25 & 39553 \\
\hline 1968 & 28884 & 9339 & 280 & 36 & 35 & 38634 \\
\hline 1969 & 26910 & 10538 & 308 & 36 & 50 & 37842 \\
\hline 1970 & 26119 & 11643 & 280 & 36 & 75 & 38153 \\
\hline 1971 & 26365 & 13092 & 220 & 45 & 100 & 39822 \\
\hline 1972 & 27296 & 14478 & 220 & 70 & 130 & 42194 \\
\hline 1973 & 28335 & 15915 & 275 & 116 & 150 & 44791 \\
\hline 1974 & 28170 & 17385 & 325 & 145 & 170 & 46195 \\
\hline 1975 & 27052 & 19055 & 350 & 188 & 185 & 46830 \\
\hline 1976 & 25956 & 21205 & 350 & 212 & 190 & 47913 \\
\hline 1977 & 25099 & 23044 & 350 & 228 & 200 & 48920 \\
\hline 1978 & 24243 & 25393 & 350 & 235 & 220 & 50441 \\
\hline 1979 & 24107 & 27935 & 350 & 235 & 235 & 52862 \\
\hline 1980 & 23764 & 30062 & 350 & 250 & 280 & 54706 \\
\hline 1981 & 23031 & 32049 & 350 & 274 & 330 & 56034 \\
\hline 1982 & 22937 & 33952 & 335 & 274 & 360 & 57858 \\
\hline 1983 & 23154 & 35804 & 320 & 279 & 380 & 59937 \\
\hline 1984 & 23228 & 37431 & 270 & 280 & 415 & 61624 \\
\hline 1985 & 23135 & 39197 & 300 & 360 & 425 & 63417 \\
\hline 1986 & 23254 & 40723 & 300 & 355 & 425 & 65057 \\
\hline 1987 & 23490 & 38959 & 300 & 420 & 415 & 63484 \\
\hline 1988 & 23077 & 37333 & 300 & 410 & 430 & 61550 \\
\hline 1989 & 22174 & 35805 & 300 & 410 & 435 & 59124 \\
\hline
\end{tabular}




\begin{tabular}{||c|c|c|c|c|c|c||}
\hline 1 & 2 & 3 & 4 & 5 & 6 & 7 \\
\hline 1990 & 21211 & 33417 & 300 & 505 & 430 & 55863 \\
\hline 1991 & 18305 & 28595 & 300 & 540 & 435 & 48176 \\
\hline 1992 & 13731 & 25155 & 300 & 540 & 435 & 40161 \\
\hline 1993 & 11536 & 22101 & 300 & 525 & 400 & 34897 \\
\hline 1994 & 11012 & 18399 & 250 & 510 & 400 & 30571 \\
\hline 1995 & 10953 & 14978 & 300 & 500 & 400 & 27131 \\
\hline 1996 & 10836 & 12085 & 300 & 450 & 400 & 24121 \\
\hline 1997 & 10829 & 11264 & 260 & 450 & 400 & 23200 \\
\hline 1998 & 10763 & 10764 & 260 & 450 & 400 & 22637 \\
\hline 1999 & 10898 & 10451 & 185 & 450 & 400 & 22184 \\
\hline 2000 & 10615 & 10201 & 185 & 470 & 400 & 21851 \\
\hline 2001 & 10491 & 9125 & 200 & 350 & 400 & 20567 \\
\hline 2002 & 10600 & 8600 & 200 & 360 & 400 & 20150 \\
\hline
\end{tabular}

Źródło: Global nuclear stockpiles, 1945-2002, „Bulletin of the Atomic Scientists”, November 1, 2002, s. 103.

Porównując stan arsenałów broni jądrowej USA i ZSRR - w 1986 roku oba te państwa razem miały ponad 63 tysiące głowic i bomb atomowych, a w rezultacie rozbrojeniowych redukcji, w 2002 roku liczba ta została zmniejszona do około 19 tysięcy.

W 1963 roku został przyjęty Układ o Zakazie Doświadczeń z Bronią Jądrową. Układ o Nierozprzestrzenianiu Broni Jądrowej (NPT - Nuclear Non-Proliferation Treaty) przedłożony do ratyfikacji w 1968 roku okazał się jednym z najbardziej skutecznych reżimów międzynarodowych, w 2005 roku przystąpiło do niego aż 189 państw ${ }^{8}$. Poza nim znajdują się jedynie takie państwa jak Izrael, Indie, Pakistan i Korea Północna. Kolejnym istotnym krokiem było podpisanie we wrześniu 1996 r. Traktatu o całkowitym zakazie prób z bronią jądrową (CNTBT - Comprehensive Nuclear-Test-Ban Treaty). W sumie 182 państwa podpisały ten traktat, a 155 do października $2011 \mathrm{r}$. zdążyło go ratyfikować, odrzucony został przez Senat USA w listopadzie 1999 roku, Duma Federacji Rosyjskiej ratyfikowała go 21 czerwca 2000 r. ${ }^{9}$ Wyzwaniem dla skuteczności CNTBT były przeprowadzone testy z bronią jądrową w maju 1998 roku przez Pakistan i Indie, które formalnie do niego nie należą. Mimo wszystko, jak podkreśla Joseph Cirincione, aż przez osiem lat, w okresie 1998-2006, co było wynikiem nadzwyczajnym jak na ,epokę atomową”, żadne z państw nie przeprowadziło testów broni jądrowej, aż do przeprowadzonej w październiku 2006 roku eksplozji „urządzenia atomowego" przez Koreę Północną ${ }^{10}$.

Już w czasie zimnej wojny rozpoczęty został dialog rozbrojeniowy przez USA i ZSRR/Rosję w kolejnych układach jak: INF (Intermediate Nuclear Forces), czy START (Strategic Arms Reduction Treaty) I i II. Układ START II nie został ratyfikowany przez Dumę Federacji Rosyjskiej oraz deklaracja SORT (Strategic Offensive

${ }^{8}$ Szerzej o reżimie NPT: J. Bryła, Rozwój i znaczenie reżimów międzynarodowych na przykładzie reżimu nieproliferacji broni jadrowej, Warszawa 2006.

${ }^{9}$ Na podstawie informacji z: CTBO Preparatory Mission, http://www.ctbto.org (22.10.2011).

10 J. Cirincione, Bomb Scare. The History and Future of Nuclear Weapons, New York 2007, s. 128 . 
Reduction Treaty), która jednak nie stanowi wiążącego układu rozbrojeniowego. W czerwcu 2002 r. administracja G. W. Busha podjęła jednostronną decyzję o wycofaniu się USA z ABM (Anti-Ballistic Missile) - układu o ograniczeniu systemów obrony przeciwrakietowej. Uzasadnieniem wyjścia z ABM była projektowana budowa tarczy antyrakietowej (Missile Defence), która miała chronić USA i jej sojuszników przed atakiem nuklearnym ze strony państw określanych przez administrację G. W. Busha mianem „hultajskich”, takich jak m.in. Korea Północna czy Iran. Doprowadziło to do pewnego kryzysu w amerykańsko-rosyjskim dialogu rozbrojeniowym. Jego przełamaniem była decyzja administracji B. Obamy o zawieszeniu prac nad MD, i wreszcie zawarcie 8 kwietnia 2010 roku przez USA i Rosję nowego układu START, który został ratyfikowany przez obie strony na początku 2011 roku. Układ wprowadził nowy reżim kontroli, zastępujący wygasły w 2009 r. w ramach START I. Nowy START ma obowiązywać przez dziesięć lat do 2021 r. i może zostać automatycznie przedłużony o kolejne pięć lat. Redukcje przewidują zmniejszenie przez obie strony liczby strategicznych głowic nuklearnych z 2200 do 1550 . Ponadto zmniejszona zostałaby liczba wyrzutni rakietowych oraz ciężkich bombowców do $700^{11}$.

Okazuje się, że w latach 1990-2010 więcej państw zrezygnowało z broni jądrowej, bądź wycofało się ze swoich programów atomowych, w porównaniu z liczbą państw, które takie działania rozpoczęły. Najbardziej wymownym przykładem było podpisanie przez władze Białorusi, Kazachstanu i Ukrainy protokołu lizbońskiego i przekazanie przez te państwa rakiet balistycznych oraz głowic nuklearnych Rosji jako spadkobierczyni ZSRR, po czym te trzy państwa przystapiły do Układu o Nierozprzestrzenianiu Broni Jądrowej. Ponadto władze Afryki Południowej poinformowały opinię publiczną w 1993 roku, że zlikwidowanych zostało 6 bomb jądrowych, będących w posiadaniu tego państwa. Oświadczenie to potwierdzało definitywne zakończenie tajnego progra$\mathrm{mu}$ atomowego. Innym optymistycznym sygnałem była decyzja podjęta jeszcze w latach osiemdziesiątych przez władze Argentyny i Brazylii o zaprzestaniu programów atomowych, które zapoczątkowały junty wojskowe. Pod koniec 2003 roku Muammar Kaddafi podjął decyzję o zaniechaniu libijskiego tajnego programu atomowego ${ }^{12}$. Przykłady te świadczą, że powyższe państwa wybrały drogę współpracy ze społecznością międzynarodową i w ramach NPT, zamiast podążania kosztowną drogą rozwijania programu atomowego, przy równoczesnym skazaniu siebie na izolację międzynarodową. Na taki krok zdecydował się totalitarny reżim w Korei Północnej. Można wskazać kilka motywów decyzji rozwijania w tym państwie programu atomowego, którego efektem było uzyskanie broni jądrowej: obawa przed ingerencją zewnętrzną, podreperowanie wizerunku zarówno na wewnętrznej scenie, jak i zewnętrznej oraz wreszcie jako instrument wymuszania/szantażowania współpracy i uzyskiwania pomocy ze strony ChRL, Japonii czy USA. Kolejnym państwem, które zdecydowało się na intensywny rozwój swojego programu atomowego jest Iran. Od 2002 roku narastają wątpliwości wokół tego programu i choć Iran formalnie jest członkiem NPT, w ocenie niektórych ekspertów, państwo to w najbliższym czasie,

11 U.S.-Russia nuclear arms treaty finalized, „USA Today”, 2.05.2011.

12 J. Cirincione, Bomb Scare. The History..., op. cit., s. 127. 
nawet w przeciagu od kilku do kilkunastu miesięcy, osiagnie zdolność do wyprodukowania broni jądrowej ${ }^{13}$.

W sumie, pod koniec 2009 roku na łączny arsenał 23360 różnych rodzajów broni jądrowej rozmieszczonych w kilkunastu miejscach na obszarze 14 państw, prawie połowa z niego była aktywna pod względem operacyjnym. Największa koncentracja tej broni, bo aż $91 \%$ znajduje się nadal na obszarze Rosji i USA. Obok pozostałych państw posiadających broń nuklearną (Wielka Brytania, ChRL, Francja, Indie, Pakistan, Izrael oraz Korea Północna), trzeba doliczyć jeszcze pięć państw będących w NATO (Belgia, Niemcy, Włochy, Holandia oraz Turcja), na których obszarze rozmieszczono w sześciu amerykańskich bazach około 200 bomb atomowych ${ }^{14}$.

Tabela 2

Szacunkowe dane związane z bronią jądrową na świecie w 2009 roku

\begin{tabular}{||l|c|}
\hline \multicolumn{1}{|c|}{ Państwo } & Liczba \\
\hline Rosja & 13000 \\
\hline Stany Zjednoczone & 9400 \\
\hline Francja & 300 \\
\hline ChRL & 240 \\
\hline Wielka Brytania & 180 \\
\hline Izrael & $80-100$ \\
\hline Pakistan & $70-90$ \\
\hline Indie & $60-80$ \\
\hline Korea Północna & $?$ \\
\hline Lączna liczba & $\mathbf{2 3 ~ 3 6 0}$ \\
\hline
\end{tabular}

Źródło: R. S. Norris, H. M. Kristensen, Nuclear Notebook: Worldwide Deployments of Nuclear Weapons, 2009, „Bulletin of the Atomic Scientists”, November/December 2009, s. 87.

\section{OPTYMIŚCI I PESYMIŚCI WOBEC PROLIFERACJI BRONI JĄDROWEJ}

Problem proliferacji i nowe państwa z bronią jądrową jak: Korea Północna czy Pakistan oraz perspektywa nuklearyzacji Iranu wpłynęły znacząco na debatę między optymistami a pesymistami. Badacze z pierwszej szkoły zajęli stanowisko, że proliferacja broni jądrowej poprzez wzajemne odstraszanie przyczynia się do ustabilizowania systemu międzynarodowego. Do głównych przedstawicieli tego nurtu należeli: Kenneth Waltz oraz John Mearsheimer, który potem jednak zajął stanowisko pesymistyczne ${ }^{15}$.

${ }^{13}$ G. Jones, An In-Depth Examination of Iran's Centrifuge Enrichment Program and Its Efforts to Acquire Nuclear Weapons, NPEC, Nonproliferation Policy Education Center, August 09, 2011.

14 R. S. Norris, H. M. Kristensen, Nuclear Notebook: Worldwide Deployments of Nuclear Weapons, 2009, „Bulletin of the Atomic Scientists”, November/December 2009, s. 87.

15 Szerzej: J. J. Mearsheimer, Nuclear weapons and deterrence in Europe, „International Security” 1984, No. 9 (3), s. 19-46; Back to the Future. Instability in Europe after the Cold War, „Internatio- 
Wyraźnie z tym podejściem kontrastuje szkoła pesymistyczna, według której trudno jest mówić o stabilizującym wzajemnym odstraszaniu, gdy weźmie się pod uwagę poważne różnice pomiędzy nowymi państwami atomowymi wynikające $\mathrm{z}$ odmiennych: potencjałów, uwarunkowań technicznych, politycznych, kulturowych, geograficznych czy organizacyjnych. Szkoła pesymistyczna zajmuje stanowisko, że niekontrolowana proliferacja broni jądrowej stanowi poważne zagrożenie dla bezpieczeństwa międzynarodowego i na pewno nie będzie oznaczała stabilizacji związanej z nuklearnym odstraszaniem państw atomowych. Pesymiści zajmują stanowisko, że niekontrolowany wyścig zbrojeń oznacza jeszcze większe ryzyko wybuchu konfliktu nuklearnego. Głównymi przedstawicielami szkoły pesymistycznej są m.in. Robert Jervis oraz Scott Sagan ${ }^{16}$.

W publikacji Kennetha Waltza - The Spread of Nuclear Weapons: More May Be Better, zostały wyłożone główne argumenty szkoły optymistycznej ${ }^{17}$. Najważniejszym przesłaniem tego podejścia było przekonanie, że podobnie jak podczas zimnowojennej rywalizacji pomiędzy USA a ZSRR, także nowe państwa atomowe nie będą wszczynały konfliktu, zdając sobie sprawę z konsekwencji odwetu przy użyciu tej broni, jak ujął to K. Waltz: „w konflikcie konwencjonalnym, nie ma pewności kto wygra, a kto przegra. Natomiast w nuklearnym świecie, nie ma pewności co do przetrwania, albo zostania zniszczonym"18. Tak samo jak w okresie zimnej wojny, państwa posiadające broń atomową są ostrożniejsze w prowadzeniu polityki zagranicznej. Proliferacja broni jądrowej oraz świadomość groźby unicestwienia w przypadku użycia tej broni, staje się czynnikiem odstraszającym dla potencjalnych agresorów. K. Waltz nie dostrzega zagrożenia w rozprzestrzenianiu broni jądrowej, uważając, że nawet rosnąca liczba atomowych państw nie musi oznaczać zagrożenia dla bezpieczeństwa międzynarodowego, a wręcz przeciwnie dzięki, ich wzajemnemu nuklearnemu odstraszaniu, system międzynarodowy nabiera stabilności, bowiem prawdopodobieństwo, że państwa posiadające broń jądrową rozpoczną wojnę jest bliskie zera. Optymizm K. Waltza opiera się na przekonaniu, że przywódcy bez względu na typ reżimu politycznego, dokonają racjonalnego wyboru, którego efektem jest unikanie konfliktu z innym państwem atomowym i ostrożniejsza polityka wobec innych państw atomowych. W swojej fundamentalnej pracy Man, the State and War w jednej z głównych tez żywi przekonanie, że „wojny wybuchają, ponieważ nie ma niczego co by je powstrzymało" ${ }^{\prime 2}$. Zaprezentowany został usystematyzowany wywód na temat trzech głównych przyczyn wojny, ich

nal Security" 1990, No. 15 (1), s. 5-56; K. N. Waltz, Nuclear Myths and Political Realities, „American Political Science Review” 1990, No. 84 (3), s. 731-745.

16 Szerzej: R. Jervis, The Illogic of American Nuclear Strategy, Ithaca 1984; The Political Effects of Nuclear Weapons: A Comment, „International Security” 1988, No. 13 (2), s. 80-90; Rational Deterrence: Theory and Evidence, „World Politics” 1998, No. 42 (2), s. 183-207; The Meaning of Nuclear Revolution: Statecraft and the Prospect of Armageddon, Ithaca 1989; S. Sagan, Moving targets: Nuclear strategy and national security, Princeton 1989; Why do states build nuclear weapons? Three models in search of a bomb, „International Security” 1996, No. 21 (3), s. 54-86; Nuclear dangers in South Asia, „Forum on Physics \& Society” 2004, No. 41 (6), s. 4-7.

17 Szerzej: K. N. Waltz, The Spread of Nuclear Weapons: More Be Better, „Adelphi Paper” 1981, No. 171.

18 Ibidem, s. 8

19 K. N. Waltz, Man, the State and War: A Theoretical Analysis, New York 1959, s. 188. 
wyjaśnienie zawarte zostało $\mathrm{w}$ trzech alternatywnych obrazach: pierwszy związany jest z naturą ludzką, drugi wynikał ze specyfiki danego reżimu politycznego i wreszcie trzeci powodowany jest przez anarchiczny system międzynarodowy, który tworzy podatny grunt dla wojen. Według tego badacza bez względu na pokojowe i różne inicjatywy polityczne poszczególnych państw, decydenci muszą uwzględniać w swoich kalkulacjach przede wszystkim ten trzeci obraz. Dopóki nie istnieje żadna nadrzędna władza, dominująca $\mathrm{w}$ systemie międzynarodowym, dopóty jedną z możliwości braną pod uwagę przez państwa, przy rozwiązywaniu rozbieżności między sobą, jest sięganie po siłę zbrojna. Ta sytuacja uległa zmianie wraz z pojawieniem się broni jądrowej. Jednak $\mathrm{K}$. Waltz daleki jest ujmowania tej broni w kategoriach czynnika doprowadzającego do zrewolucjonizowania systemu międzynarodowego, w którym wyeliminowana została wojna. W tym przypadku zasadniczą rolę odgrywa strach przed niszczycielskimi skutkami wojny jądrowej dla cywilizacji i rodzaju ludzkiego, jednak nie jest to, jak podkreśla, warunek dla rzeczywistego pokoju, który wynikałby z innych przesłanek, aniżeli obawy przed unicestwieniem ${ }^{20}$. Badacz jest przekonany, że odstraszanie nie opiera się na racjonalnych przesłankach, ale generuje go strach, bez broni jądrowej nie byłoby to możliwe ${ }^{21}$. Jej całkowite usunięcie, zamiast uczynić świat bezpieczniejszym, doprowadziłoby w ocenie tego badacza, do ożywienia różnego rodzaju konfliktów, do tej pory uśpionych nuklearnym pokojem, wynikających $\mathrm{z}$ anarchicznego charakteru systemu międzynarodowego.

Szkoła pesymistyczna nie dostrzega w proliferacji możliwości uniknięcia wojen przez nuklearne odstraszanie, wręcz przeciwnie, w ocenie przedstawicieli tego podejścia, wraz z nowymi atomowymi państwami rośnie ryzyko konfliktu, albo ataku terrorystycznego z wykorzystaniem tej broni ${ }^{22}$. W ocenie nuklearnych pesymistów, przekonanie, że w policentrycznym świecie broń jądrowa będzie odgrywać podobną rolę jak w czasie zimnej wojny, jest całkowicie nieuzasadnione. Wszelkie odnoszenie zimnowojennych modeli związanych $\mathrm{z}$ atomowym pokojem nie ma pokrycia w obecnej sytuacji. Jak zauważył Scott Sagan, broń jądrowa jako jedna z najbardziej niszczycielskich w historii ludzkości tylko pozornie odstrasza potencjalnych rywali przed wojną atomową. Rzeczywistość jest bardziej skomplikowana, a zarazem niebezpieczna, ponieważ broń ta znajduje się pod kontrolą ułomnej natury ludzkiej i równie ułomnych systemów politycznych. To czynnik ludzki jest źródłem niepokoju ${ }^{23}$. Wystarczy błędna kalkulacja, fałszywe założenia oraz zwykły błąd, który może doprowadzić do użycia tej broni przez którąś ze stron ${ }^{24}$. Kolejnym problemem jest fakt, że proliferacja broni jądrowej w sytuacji, w której obok kolejnych państw także grupy terrorystyczne mogą uzyskać

20 Ibidem, s. 236.

${ }^{21}$ N. J. Wheeler, Beyond Waltz's nuclear world: more trust may be better, w: Realism and World Politics, ed. K. Booth, New York 2011, s. 266.

22 Szerzej: S. P. Kapur, Dangerous Deterrent: Nuclear Weapons Proliferation and Conflict in South Asia, Stanford 2007.

${ }^{23}$ Robert Jervis podjął tematykę sposobu postrzegania zagrożeń przez decydentów w: Perception and Misperception in International Politics, Princeton 1976.

${ }^{24}$ S. Sagan, K. Waltz, R. K. Betts, A Nuclear Iran: Promoting Stability or Courting Disaster, „Journal of International Affairs", Spring/Summer 2007, Vol. 60, s. 135. 
dostęp do broni atomowej, powoduje że w zasadzie bardzo trudno jest prowadzić skuteczną politykę odstraszania wobec niepaństwowych podmiotów.

Inspiracją dla debaty na temat konsekwencji rozprzestrzeniania broni jądrowej stanowi przykład Indii i Pakistanu. Oba państwa znajdują się w trwającym od wielu dekad konflikcie, a dodatkowy komponent w postaci broni nuklearnej po jednej i drugiej stronie wpływa na ich wzajemne relacje. Pakistan w ostatnich latach szczególnie intensywnie rozbudowuje swój arsenał atomowy ${ }^{25}$. Na podstawie analizy wywiadowczej USA z 2008 roku, okazało się, że Pakistan w ostatnich latach wyprodukował najwięcej broni jądrowej w porównaniu $z$ innymi atomowymi państwami i to pomimo jego katastrofalnej sytuacji gospodarczej ${ }^{26}$. Według „Bulletin of the Atomic Scientists”, Pakistan w 2009 roku miał, na podstawie różnych szacunków, od 70 do 90 głowic, gdy w 2011 roku liczba ta zwiększyła się do przedziału: $90-110^{27}$.

Zdaniem Scotta Sagana, można wskazać co najmniej trzy zagrożenia związane $\mathrm{Z}$ atomowym Pakistanem:

1) państwo to może prowadzić bardziej agresywną politykę wobec sąsiadów, mając świadomość, że chroni je atomowa tarcza;

2) istnieje poważne ryzyko przejęcia broni jądrowej przez terrorystów;

3) problem z nieszczelnym systemem kontroli nad pakistańskim arsenałem nuklearnym.

Ad. 1. W Pakistanie system podejmowania decyzji nie jest tak scentralizowany jak był w przypadku Związku Radzieckiego. Różne grupy interesów, zwłaszcza wojskowe, mają wpływ na politykę państwa. Jednym z tego przykładów wpływu kół wojskowych było zmuszenie premiera Nawaza Szarifa, w 1998 roku, na wyrażenie zgody na bardzo ryzykowną operację, w której pakistańskie oddziały przebrane za mudżahedinów wtargnęły na indyjską stronę Kaszmiru w pobliże miasta Kargil. W sytuacji, kiedy Indie zagroziły odwetem, pakistański premier ostatecznie zdecydował się na wycofanie sił, aby nie doszło do eskalacji, łącznie z użyciem broni jądrowej. W ocenie S. Sagana oba atomowe państwa znalazły się na krawędzi i stąd już bardzo szybko do podjęcia decyzji o użyciu broni jądrowej ${ }^{28}$. Konfliktogenne sąsiedztwo, niestabilny kontekst regionalny, różne grupy interesów i często błędna ocena sytuacji, prowadzi do powiększonego ryzyka użycia broni jądrowej. W przypadku Indii i Pakistanu bezpośrednie sąsiedztwo oraz głęboka nieufność obu atomowych państw względem siebie, ma zupełnie inny charakter aniżeli zimnowojenna rywalizacja pomiędzy USA a ZSRR, która przede wszystkim toczyła się na peryferiach, a rzadziej na żywotnym dla bezpieczeństwa tych supermocarstw obszarze. Rywalizacja pomiędzy Indiami a Pakistanem określona została jako paradoks stabilności/niestabilności, polegający na tym, że z jednej strony Indie i Pakistan, unikając wybuchu konwencjonalnego konfliktu pomiędzy

25 K. DeYoung, New estimates put Pakistan's nuclear arsenal at more than 100, „Washington Post", 31.01.2011.

${ }^{26}$ K. DeYoung, G. Miller, WikiLeaks cables show US focus on Pakistan's military, nuclear material', „Washington Post”, 1.12.2010.

27 H. M. Kristensen, R. S. Norris, Pakistan's Nuclear Forces, 2011, „Bulletin of the Atomic Scientists", 67(4) 2011, s. 91-92. Warto przypomnieć w tym miejscu, że prognozy US Defense Intelligence Agency z 1999 roku mówiły o tym, że Pakistan w 2020 roku będzie miał od 60 do 80 głowic.

${ }^{28}$ S. Sagan, K. Waltz, R. K. Betts, A Nuclear..., op. cit., s. 140. 
soba, z drugiej nadal stosują wobec siebie przemoc, utrzymując bez przerwy konflikt o niskiej intensywności, przede wszystkim przez wspieranie działalności terrorystycznej wymierzonej w adwersarza. Posiadanie broni atomowej sprzyja występowaniu konfliktu o niskiej intensywności, który staje się najbardziej bezpiecznym środkiem do osłabiania rywala w dłuższej perspektywie ${ }^{29}$. Istnieje ryzyko, że konflikt o niskiej intensywności może przerodzić się w pełnowymiarową wojnę wraz z użyciem $\mathrm{w}$ niej broni jądrowej.

Ad. 2. Według doniesień „Washington Post”, w czasie kryzysu pomiędzy Indiami a Pakistanem o Kargil, w 1999 roku, wywiad pakistański oraz służby bezpieczeństwa rozważały czasowe przeniesienie broni jądrowej do sąsiedniego Afganistanu, z obawy przed zniszczeniem jej przez lotnictwo indyjskie ${ }^{30}$. Być może przeniesienie broni, uchroniłoby ją przed ewentualnym uderzeniem indyjskim, ale równocześnie znacznie wzrosłoby ryzyko, przejęcia jej przez talibów albo Al-Kaidę. Takie ryzyko jest także w samym Pakistanie. Rozproszenie infrastruktury związanej z rozwijanym intensywnie programem atomowym oraz nieszczelny system kontroli może zachęcić różne ekstremistyczne grupy do próby przejęcia choćby części arsenału nuklearnego. Tego typu obawy dodatkowo zostały wzmocnione faktem, że Osama ibn Laden ukrywał się przez lata w pakistańskim Abbotabadzie, oddalonym jedynie o 16 kilometrów od dużego podziemnego składu broni, w którym prawdopodobnie znajdowały się komponenty broni jądrowej. Natomiast dla władz pakistańskich sporym zaskoczeniem była łatwość z jaką Amerykanie dokonali rajdu w głąb ich państwa by zlikwidować ibn Ladena, następnym razem mogli przecież uderzyć by zneutralizować, bądź przejąć pakistańską broń jądrową. Stąd w ocenie wielu badaczy na problem indyjsko-pakistańskiej rywalizacji atomowej nakłada się nie tyko kontekst regionalnego konfliktu o granice, ale dodatkowo jeszcze niestabilna sytuacja wewnętrzna Pakistanu, w którym obok korupcji, ekonomicznej niewydolności, występuje konflikt pomiędzy sunnitami a szyitami oraz różnymi grupami etnicznymi, nie mówiąc już o wzbierającej fali ekstremizmu. Wojna domowa w tym państwie może oznaczać przejęcie broni jądrowej przez różne zwalczające się grupy i frakcje, ale również i terrorystów ${ }^{31}$.

Ad. 3. Abdul Qadeer Khan, główna postać pakistańskiego programu atomowego, wraz z innymi naukowcami i wieloma firmami, stworzył sieć sprzedaży technologii jądrowej. Miarą jej skuteczności była kompleksowość usług wobec państw-klientów chcących rozwijać swoje programy atomowe. Nuklearna sieć Khana nie tylko dostarczała gotowych projektów i dokumentacji, ale także posiadała oferty firm z nią kooperujących, które gotowe były dostarczyć niemal każdy technologiczny element niezbędny do rozwijania programu atomowego. Projekty bomb atomowych oraz technologie wirówek i inne elementy odsprzedane zostały m.in.: Libii, Korei Północnej oraz Iranowi. W 1991 roku przedstawiciele nuklearnej sieci A. Q. Khana złożyli ofertę

${ }^{29}$ W opinii Kennetha Waltza paradoks stabilności/niestabilności powoduje, że państwa posiadające broń atomową, skłonne sąjedynie do prowadzenia przeciwko sobie tzw. „małych wojen”. Por.: K. N. Waltz, For Better: Nuclear Weapons Preserve an Imperfect Peace, w: The Spread of Nuclear Weapons: A Debate Renewed, eds. S. Sagan, K. Waltz, New York 2003, s. 122.

${ }_{30}$ M. Moore, K. Khan, Pakistan Moves Nuclear Weapons, „Washington Post”, 11.11.2001.

31 G. Perkovich, Nuclear-Weapons Tests in South Asia Prove That the Nonproliferation Regime has Failed, „Foreign Policy”, 1.09.1998, s. 16. 
Irakowi, jednak Saddam Husajn ją odrzucił, bowiem był przekonany, że mogła to być prowokacja CIA ${ }^{32}$.

Niestabilny wewnętrznie Pakistan z nieuregulowanym konfliktem z Indiami dał sporo argumentów szkole pesymistycznej. Choć optymiści uważają że oba atomowe państwa unikają eskalowania konfliktu pomiędzy sobą, a nawet zaczynają prowadzić ze sobą dialog, tak jak niegdyś USA i ZSRR, to jednak pesymiści przypominaja, że przez proliferację broni jądrowej, szczególnie w przypadku Pakistanu wzrosło ryzyko przejęcia jej przez grupy terrorystyczne, nuklearna sieć Khana ułatwiła dostęp do technologii atomowej Korei Północnej, Iranowi czy Libii, być może także podmiotom niepaństwowym.

$\mathrm{Na}$ obecną debatę wpływ ma także problem irańskich aspiracji atomowych. O ile w przypadku Indii czy Pakistanu, a także Korei Północnej, programy atomowe realizowane były poza NPT, o tyle przypadek Iranu jest szczególny, bowiem to państwo uczestniczy w tym reżimie i w jego ramach podlega systemowi kontroli ze strony Międzynarodowej Agencji Energii Atomowej. Jeśli Iran uzyska broń jądrową, osłabi w znaczący sposób reżim nieproliferacji. Nuklearny program, nabierający w ostatnich latach rozmachu, stanowi rozbudowane przedsięwzięcie, obok licznych rozproszonych instytutów i ośrodków, na trzy główne składają się: kopalnia uranu w Saghandzie, ośrodek wzbogacania uranu w Natantzu, główny ośrodek do produkcji ciężkiej wody w Arak. Władze irańskie w umiejętny sposób wykorzystują fakt nieszczelności systemu kontroli oraz pomimo kolejnych rezolucji i sankcji, dalej intensywnie rozwijany jest program atomowy.

Tabela 3

\section{Rezolucje RB ONZ wzywające Iran do współpracy oraz sankcje nałożone na to państwo}

\begin{tabular}{||l|l||}
\hline $\begin{array}{l}\text { Rezolucja 1696, } \\
\text { 11 lipca 2006 roku }\end{array}$ & $\begin{array}{l}\text { W rezolucji zwrócono się do Iranu o wstrzymanie wzbogacania uranu do 31 sierpnia 2006 } \\
\text { roku i w przypadku niewypełnienia jej, zagrożono sankcjami }\end{array}$ \\
\hline $\begin{array}{l}\text { Rezolucja } 1737 \\
23 \text { grudnia } 2006 \text { roku }\end{array}$ & $\begin{array}{l}\text { Nałożono na wszystkich członków ONZ zakaz sprzedaży Iranowi materiałów lub techno- } \\
\text { logii, które mogą zostać wykorzystane w irańskim programie jądrowym i rakietowym. } \\
\text { Z zakazu wyłączona została Federacja Rosyjska, zaangażowana w budowie w Busherze } \\
\text { pierwszej irańskiej elektrowni jądrowej. Zamrożono też zagraniczne aktywa dziesięciu } \\
\text { irańskich firm związanych z przemysłem jądrowym. }\end{array}$ \\
\hline $\begin{array}{l}\text { Rezolucja } 1747 \\
24 \text { marca } 2007 \text { roku }\end{array}$ & Rozszerzenie zakresu sankcji i m.in. nałożenie embarga na eksport broni z Iranu. \\
\hline $\begin{array}{l}\text { Rezolucja } 1803 \\
3 \text { marca } 2008 \text { roku }\end{array}$ & $\begin{array}{l}\text { Kolejne rozszerzenie listy osób i instytucji, wobec których wprowadzono sankcje finan- } \\
\text { sowe oraz ograniczenia podróży irańskich urzędników nadzorujących program atomowy. } \\
\text { Równocześnie w dokumencie zwrócono uwagę na możliwość powrotu do dialogu, pod- } \\
\text { kreślając iż społeczność międzynarodowa nie ma nic przeciwko cywilnemu programowi } \\
\text { atomowemu. }\end{array}$ \\
\hline $\begin{array}{l}\text { Rezolucja } 1835 \\
27 \text { września } 2008 \text { roku }\end{array}$ & $\begin{array}{l}\text { RB ONZ wezwała Iran do zastosowania się wobec poprzednich sankcji, nie nakładając } \\
\text { nowych i potwierdziła gotowość do dialogu z władzami irańskimi. }\end{array}$ \\
\hline $\begin{array}{l}\text { Rezolucja } 1929 \\
9 \text { czerwca } 2010 \text { roku }\end{array}$ & $\begin{array}{l}\text { Zaostrzenie sankcji. Zakaz eksportowania do Iranu ciężkiego uzbrojenia, prawo do kon- } \\
\text { trolowania irańskich statków oraz samolotów podejrzanych o transport objętych sankcjami } \\
\text { ładunków. Ponadto objęto zakazem zagraniczną działalność Iranu związaną z technolo- } \\
\text { giami nuklearnymi. }\end{array}$ \\
\hline
\end{tabular}

Źródło: Opracowanie własne na podstawie United Nations (UN) Security Council Resolutions 1696, 1737, 1747, 1803, 1835, 1929, http://www.un.org/engilsh (23.10.2011).

32 Szerzej o sieci A. Q. Khana: G. Cerera, Shopping for bombs. Nuclear proliferation, global insecurity, and rise and fall of the A. Q. Khan network, Oxford 2006. 
Na podstawie różnych analiz oraz przewidywań, Iran z bronią nuklearną może wywołać następujące skutki ${ }^{33}$ :

- przyspieszenie proliferacji broni jądrowej na Bliskim Wschodzie. Inne państwa widząc słabość reżimu o nierozprzestrzenianiu broni jądrowej, także zaczną rozwijać swoje programy atomowe. Będzie to poważne osłabienie NPT, jak do tej pory jednego z najbardziej skutecznych reżimów międzynarodowych. Część państw uczyni to z powodu obawy przed nuklearnym Iranem. Może nawet dojść do efektu domina w tym regionie, irańska broń jądrowa może doprowadzić do nuklearyzacji: Arabii Saudyjskiej przez prawdopodobny zakup broni jądrowej, Egiptu, Syrii, Iraku, Turcji czy Algierii, w tym wypadku przez intensywnie rozwijane programy atomowe. Nuklearna rywalizacja pomiędzy tymi państwami może doprowadzić do bliskowschodniego wyścigu zbrojeń, bardzo kosztownego dla ich społeczeństw ${ }^{34}$;

- zwiększonego wspierania różnego rodzaju grup paramilitarnych i terrorystycznych, których aktywność skierowana jest przeciwko USA i jego sojusznikom na Bliskim Wschodzie, a szczególnie wymierzonego w osłabianie Izraela. Istnieje ryzyko przekazania przez Teheran tym grupom komponentów do zbudowania „brudnej bomby";

- poważne wyzwanie dla bezpieczeństwa energetycznego. Możliwość zablokowania przez Iran Cieśniny Ormuz, która stanowi newralgiczne połączenie pomiędzy polami roponośnymi w państwach nadbrzeżnych Zatoki Perskiej, a Zatoką Omanu i Oceanem Indyjskim. Przepływa przez nią około $88 \%$ paliwa eksportowanego przez państwa Zatoki Perskiej. Stanowi to około 20\% dziennego światowego zapotrzebowania na ropę. $25 \%$ importowanej przez Stany Zjednoczone ropy przepływa na tankowcach przez cieśninę Ormuz. Dla przykładu aż 75\% importowanego przez Japonię paliwa przepływa przez tę cieśninę, a około 20\% do Europy Zachodniej ${ }^{35}$;

- powstanie kolejnej nuklearnej sieci ułatwiającej sprzedaż elementów potrzebnych do rozwijania programów atomowych, szczególnie tym państwom, które gotowe byłby w tym obszarze współpracować z Iranem zarówno w regionie, jak i poza nim.

Nuklearyzacja Bliskiego Wschodu jest kolejnym wyzwaniem, w regionie w którym, z jednej strony wiele państw ma ze sobą nieuregulowane kwestie sporne wraz z rywalizacją kilku pretendentów o regionalne przywództwo, a z drugiej, większość z nich jest niestabilna wewnętrznie. „Arabska wiosna” pokazała swoją siłę i doprowadziła jak dotąd do upadku rząóow M. Kaddafiego, H. Mubaraka czy Ben Alego, ale także stała się wyzwaniem dla systemu autorytarnego w Syrii. Najwięcej walk wewnętrznych toczyło się w Libii, przy wsparciu sił powietrznych NATO, w której także po śmierci M. Kaddafiego, nadal rzeczywistą władzę mają różne paramilitarne grupy. Jak bardzo groźna byłaby sytuacja, gdyby te grupy zbrojne, często skłócone ze sobą, przejęłyby

33 Np. Getting Ready for a Nuclear Iran, eds. H. Sokolski, P. Clawson, Strategic Studies Institute, October 2005.

34 R. Fiedler, Od przywództwa do hegemonii. Stany Zjednoczone wobec bliskowschodniego obszaru niestabilności w latach 1991-2009, Poznań 2010, s. 316-323.

35 Ibidem, s. 317. 
część, albo cały libijski arsenał atomowy. Na szczęście reżim M. Kaddafiego wcześniej zrezygnował z programu atomowego, ale to bardzo dobrze ilustruje skalę zagrożenia, np. hipotetycznego upadku za kilkanaście lat monarchii saudyjskiej, pod wpływem czynników wewnętrznych, w której znajdują się liczne składy z bronią nuklearną. Przykładowo po upadku ZSRR, Stany Zjednoczone były zaangażowane w pomoc dla Federacji Rosyjskiej w zabezpieczaniu licznych magazynów oraz obiektów nuklearnych, wiele z nich było bardzo słabo strzeżonych, nie mówiąc już o niedokładnej inwentaryzacji. Choć przemiany w Rosji, w przeważającej mierze nie miały gwałtownego charakteru, a mimo wszystko są podejrzenia, że zanim został usprawniony system kontroli, część nuklearnych elementów zostało prawdopodobnie skradzionych i przemyconych poza granice Rosji.

Słabnący czynnik odstraszania po zimnej wojnie jest jednym z poważnych problemów związanych z proliferacją broni jądrowej ${ }^{36}$. Terrorystyczne ataki z 11 września 2001 r. uwidaczniają, że przesłaniem istotnym dla terrorystów są zarówno olbrzymia liczba ofiar, jak i skala zniszczeń. Pesymiści zadają retoryczne pytanie - jak może zadziałać czynnik odstraszania wobec terrorystycznej grupy, której komórki rozlokowane są w rozlicznych miejscach na świecie?

Brian Jenkins już w latach siedemdziesiątych w jednej ze swoich prac przedstawił całe spektrum możliwości związanych z bronią jądrową bądź radioaktywnym materiałem, które mogą zostać wykorzystane przez terrorystów w rozmaity sposób:

- wysadzenie „brudnej bomby” i skażenie radioaktywne na obszarze gęsto zaludnionego miasta, konsekwencją takiego ataku obok ofiar byłyby jeszcze poważna panika nie tylko w mieście dotkniętym takim atakiem;

- sabotaż albo atak skierowany w elektrownię atomową, choć prawdopodobnie nie doprowadziłby do znacznego radioaktywnego wycieku, ale skupiłby uwagę opinii publicznej, co pewnie wywołałoby panikę wśród ludności mieszkającej w pobliżu elektrowni atomowej;

- przejęcie kontroli nad przykładową elektrownią atomową i groźba jej wysadzenia w razie nie spełnienia żądań stawianych przez terrorystów;

- kradzież broni jądrowej, ale także sama jej próba, w niewątpliwy sposób będzie wystarczająco silnym wstrząsem dla opinii publicznej, nawet jeśli celem terrorystów nie tyle będzie użycie tej broni, co bardziej zwrócenie na siebie uwagi;

- detonację bomby atomowej, albo sama jej zapowiedź. Atak przeprowadzony w gęsto zaludnionym mieście doprowadziłby do olbrzymich ofiar i zniszczen ${ }^{37}$.

Broń jądrowa dla terrorystów jest dość atrakcyjną opcją, choć technologia atomowa jest bardzo kosztowna i właściwie możliwa jedynie jako przedsięwzięcie podjęte przez państwo, nie wspominając o problemie w składowaniu materiałów rozszczepialnych, to jednak wraz z kolejnymi państwami atomowymi oraz funkcjonowaniem nuklearnych sieci jak A. Q. Khana, mogą one znacznie ułatwić terrorystom dostęp do niej. Broń jądrowa daje terrorystom bardzo silne argumenty w zastraszaniu państw i wymu-

36 D. Gouré, Nuclear Deterrence, Then and Now, „Policy Review”, December 2002/January 2003, s. 43-55.

37 B. M. Jenkins, The Consequences of Nuclear Terrorism, w: International Political Effects of the Spread of Nuclear Weapons, ed. J. K. King, Washington 1979. 
szaniu na nich ustępstw, których by bez niej prawdopodobnie nie uzyskali. Jednak nie wszystkie grupy terrorystyczne mogą dążyć za pomocą broni jądrowej do osiagnięcia swoich celów politycznych. Istnieje ryzyko, że terrorystyczne organizacje o charakterze apokaliptycznym, $w$ imię wyznawanych przez siebie przekonań, mogą nie mieć specjalnych skrupułów przed użyciem tej broni i nie będą zainteresowane szantażem atomowym.

$$
* * *
$$

Optymiści i pesymiści wnieśli istotny wkład do debaty na temat proliferacji broni jądrowej. Głównym przedstawicielem szkoły optymistycznej jest K. N. Waltz, jego argumentacja o ostrożniejszej polityce państw posiadających broń jądrową oraz nuklearne odstraszanie, prowadzi do sytuacji, że państwa coraz rzadziej będą sięgać do siły zbrojnej, jako instrumentu swojej polityki zagranicznej. Analiza zaproponowana przez K. N. Waltza, dotyczy przede wszystkim systemu państwocentrycznego, w którym rządy państw, bez względu na ustrój polityczny, zachowują się racjonalniej, bowiem zdają sobie doskonale sprawę z konsekwencji wojny nuklearnej. Częściowym potwierdzeniem tez K. N. Waltza jest sytuacja Indii oraz Pakistanu, które od swoich atomowych testów przeprowadzonych w $1998 \mathrm{r}$. poza kilkoma incydentami, nie zdecydowały się na otwarty konflikt pomiędzy sobą. Optymiści podkreślają że państwa te zdecydowały się nawet na rozpoczęcie ze sobą dialogu, którego by nie było, gdyby nie straszak w postaci ich nuklearnych arsenałów. Perspektywa nuklearyzacji Iranu dla optymistów nie jest jakimś poważnym zagrożeniem, doprowadzi w ich przekonaniu do stabilizacji Bliskiego Wschodu. Wobec anarchizacji systemu międzynarodowego, broń jądrowa jawi się jako najskuteczniejszy gwarant bezpieczeństwa i jest jedynym efektywnym środkiem, dzięki któremu problem wojny w stosunkach międzynarodowych zostanie prawie całkowicie zmarginalizowany.

Z kolei, według przedstawicieli szkoły pesymistycznej, nie można w żaden sposób odnosić analizy dotyczącej rywalizacji atomowej pomiędzy USA a ZSRR do realiów świata po zimnej wojnie. Obok państw występują także różni inni aktorzy, jak grupy terrorystyczne. Kolejną kwestią, która musi zostać wzięta pod uwagę jest kruchość niektórych państw, które są albo znajdują się przed długotrwałymi konfliktami wewnętrznymi, a ich upadek stawia zasadnicze pytanie - co z ich arsenałami nuklearnymi? Pesymiści podkreślają, że problem tkwi w ułomnej naturze ludzkiej, krótko mówiąc decyzja o użyciu broni jądrowej może zostać podjęta na podstawie błędnej kalkulacji, która jest niestety ze względu na oczywiste ograniczenia dość prawdopodobna. Pesymistów niepokoi niestabilność wewnętrzna Pakistanu posiadającego rozbudowany arsenał nuklearny, nie mówiąc już o tym, że państwo to stało się poprzez nuklearną sieć A. Q. Khana eksporterem technologii oraz atomowego know-how. Także wobec nuklearnych aspiracji Iranu, pesymiści zajmują stanowisko, że państwo to z bronią jądrową pogłębi niestabilność $\mathrm{w}$ regionie i prawdopodobne będzie znaczące osłabienie reżimu NPT przez zdecydowanie się przez część pozostałych państw na uruchomienie własnych programów atomowych. Jednak największym zagrożeniem związanym z proliferacją jest możliwość przejęcia broni jądrowej przez terrorystów. Rozwój sieci nuklearnych i postępująca proliferacja ułatwia terrorystom, ale także zorganizowanym grupom 
przestępczym dostęp do broni jądrowej. W tej sytuacji czynnik do którego przywiązywali taką wagę optymiści, w przypadku aktorów niepaństwowych, traci rację bytu. Jak do tej pory barierą dla terrorystów są m.in. bardzo wysokie koszty oraz problem bezpiecznego składowania materiałów radioaktywnych, to niewykluczone, iż w nawet najbliższej przyszłości nie sięgną po broń jądrową jako narzędzie ułatwiające osiagnięcie założonych celów.

Obie szkoły zaprezentowały swoje odmienne stanowiska, które jednak łączy wspólne przekonanie, że proliferacja broni jądrowej jest nieunikniona i nie da się jej powstrzymać. Choć pojawiają się rozbieżności między nimi co do konsekwencji postępującego rozprzestrzeniania broni jądrowej, to jednak niewiele uwagi zostało poświęcone kwestii - co zrobić, aby jej rozprzestrzenianie znacznie ograniczyć, a także w jaki sposób doprowadzić do podniesienia efektywności reżimu nieproliferacji broni jądrowej.

To w tej chwili powinien być kluczowym problem w debacie między nimi, także rewidujący dotychczasowe stanowiska. Prawdopodobne uzyskanie przez Iran statusu atomowego obrazuje niestety kryzys reżimu nieproliferacji ${ }^{38}$. Novum polega na tym, że państwo to rozwija program atomowy i jak dotąd nie wystapiło z NPT. Bez podniesienia jego efektywności, a wraz z nią usprawnieniem procedur kontrolnych, kolejne państwa mogą podążyć śladem Iranu. Optymiści i pesymiści skupiają się na skutkach proliferacji, a przecież równie istotnym problemem jest jej powstrzymanie. Temat ten jak dotąd nie doczekał się wyczerpujących analiz.

\section{STRESZCZENIE}

Problem proliferacji broni jądrowej został pokazany z dwóch perspektyw: szkoły optymistycznej i pesymistycznej. W stanowisku optymistów proliferacja ujmowana nie jest jako zagrożenie, a bardziej skuteczne nuklearne odstraszanie. Optymiści uważają że od czasów zimnej wojny niewiele się zmieniło i nuklearne odstraszanie będzie odgrywać ważną rolę w zapobieganiu wielu potencjalnym konfliktom. Przedstawiciele tego nurtu są przekonani, że decydenci posiadający arsenał nuklearny, bez względu na ustrój polityczny będą zachowywać się racjonalnie w prowadzeniu polityki zagranicznej, w szczególności wobec innych państw atomowych. Szkoła pesymistyczna zajmuje przeciwne stanowisko. Według pesymistów, proliferacja zwiększa prawdopodobieństwo wybuchu wojny nuklearnej z powodu: ryzyka przejęcia broni jądrowej przez terrorystów, czynnik ludzki, w którym decydenci mylnie odczytując intencje swojego adwersarza mogą sięgnąc po broń jądrową oraz przez tworzenie nuklearnych sieci, ułatwiających proliferację. Szkoła pesymistyczna upatruje w broni jądrowej szczególne niebezpieczeństwo dla rodzaju ludzkiego, a jej niekontrolowane rozprzestrzenianie jeszcze bardziej to ryzyko wzmaga. Przedstawicieli obu szkół łączy przekonanie, że proliferacja będzie dalej postępować, ale co do jej skutków są już odmiennego zdania.

38 Szerzej: R. Johnson, Rethinking the NPT's Role in Security: 2010 and Beyond, „International Affairs" 2010, No. 86 (2), s. 429-445. 


\title{
PESSIMISTS AND OPTIMISTS. TWO APPROACHES TO THE PROBLEM OF NUCLEAR PROLIFERATION AFTER THE COLD WAR
}

\begin{abstract}
Nuclear proliferation is shown from two perspectives: optimists and pessimists. In the optimists' attitude nuclear proliferation is a very reliable and effective nuclear deterrent. Optimists attribute a nuclear deterrence in preventing potential conflicts. For optimists, politicians possessing nuclear arsenal regardless from the political system tend to behave more rationally, especially to other nuclear states. In pessimist's attitude, nuclear proliferation is a threat and enhances a risk of nuclear war, because: terrorists takeover or theft of nuclear bomb, human factor in miscalculation about intentions of the other side, and by developing a nuclear nets, which facilitates buying a nuclear technology and know-how. Pessimists perceive nuclear proliferation as a threat for a human-being and civilization. Representatives of these two schools agree that nuclear proliferation will be proceed further because it is still an attractive option not only for states.
\end{abstract}

